\title{
POLA PENANAMAN KARAKTER MULIA TERHADAP ANAK DIDIK DALAM KELUARGA BERDASARKAN NILAI YANG TERKANDUNG DALAM HADITS
}

\author{
Muhammad Darwis Dasopang \\ IAIN Padangsidimpuan \\ Email: darwisdasopang@iain-padangsidimpuan.ac.id
}

\begin{abstract}
Education is the most important part in human life who has morals and progress. Education can be carried out by everyone in an educational institution, but the primary education should be implemented through family education which is instilled by parents towards their family members from an early age. For this paper, the author will describe the nature and understanding of education in the family; What are the hadiths about education in the family; how the methods and aspects of family education based on the hadiths. The author uses the literature review (library research), with the primary data sources from the hadiths relating to children's education in the family. Study in this paper, Islamic education requires a simultaneous process and sustainable which involves aspects of disciplinary learning and compliance to implement Islamic education towards students. Education in the family, can be found patterns that must be implemented in the family environment, for the formation of a happy family according to what was taught by the prophet Muhammad SAW, and according to the word of Allah SWT in Q.S. Lukman: 13-19.
\end{abstract}

Keywords: Education, children, Islam and Noble Morals

\begin{abstract}
Pendidikan merupakan bagian terpenting dalam membentuk kehidupan manusia yang memiliki Akhlak karimah dan berkemajuan. Pendidikan dapat dilaksanakan oleh setiap individu pada lembaga pendidikan, namun pendidikan utama yang hendaknya dilaksanakan melalui pendidikan keluarga yang di tanamkan oleh orang tua terhadap anggota keluarganya sejak usia dini. Penulis menguraikan bagaimana hakikat dan pengertian pendidikan dalam keluarga; Apa saja hadits tentang pendidikan dalam keluarga; bagaimana metode dan Aspek-aspek pendidikan keluarga berdasarkan hadits. Penulis menggunakan metode kajian literatur (library research), dengan sumber data primer yaitu dari Hadits-hadits yang berkaitan dengan pendidikan anak dalam keluarga. Kajian dalam tulisan ini, pendidikan keislaman membutuhkan proses yang simultan dan berkesinambungan yang melibatkan aspek-aspek pembelajaran kedisiplinan dan kepatuhan untuk mengimplementasikan pendidikan keislaman terhadap anak didik. Pendidikan dalam keluarga, dapat di temukan polapola yang harus di implementasikan dalam lingkungan keluarga, untuk
\end{abstract}


118 | TAZKIR: Jurnal Penelitian Ilmu-ilmu Sosial dan Keislaman

Vol. 06 No. 1 Juni 2020

terbinanya keluarga bahagia sesuai yang di ajarkan oleh nabi muhammad SAW, dan sesuai dengan firman Allah SWT pada QS. Lukman: 13-19.

Kata Kunci : Pendidikan, anak, keislaman, dan Akhlak mulia.

\section{PENDAHULUAN}

Setiap manusia membutuhkan pendidikan yang sangat mutlak dalam menjalankan kehidupan, serta manusia tidak terlepas dari kegiatan pendidikan, sebab pendidikan merupakan suatu kebutuhan hidup setiap insan manusia untuk membentuk dan mempersiapkan pribadi yang memiliki akhlak karimah. (Yasin, 2008, p. 15) Pendidikan dapat membentuk dan menumbuh kembangkan intelektual dan spritual anak untuk tumbuh menjadi pribadi yang terdidik serta mampu dalam menghadapi persoalan kehidupan,baik dalam lingkungan keluarga bermasyarakat, berbangsa, serta persoalan masyarakat secara umum. (Asfiyah \& Ilham, 2019, p. 2) Tentunya seorang anak hendaknya mampu dalam mematangkan sikap emosi, mental, dan psikologis seorang anak tersebut.

Lingkungan keluarga merupakan lingkungan pendidikan yang pertama dan utama, karena keluargalah pertama kali yang dapat memberikan pendidikan dan bimbingan kepada anak. Selain itu lingkungan keluarga merupakan tempat pertama dan utama bagi perkembangan anak. Apabila suasana pada lingkungan keluarga itu baik dan menyenangkan, maka anak tersebut akan tumbuh dan berkembangan dengan baik. Jika sebaliknya, maka pertumbuhan anak tersebut akan terhambat. Maka dari itu proses pendidikan yang paling banyak diterima oleh anak adalah dalam lingkungan keluarga. (Asfiyah \& Ilham, 2019, p. 2)

Ditinjau berdasarkan perspektif pendidikan, lembaga pendidikan yang pertama dan utama dalam kehidupan manusia adalah lingkungan keluarga, anaknya berperan sebagai murid, dan kedua orang tua berperan sebagai gurunya. Pendidikan ini telah dimulai sejak manusia dalam rahim Ibunya. Pendidikan dalam lingkungan keluarga adalah kunci bagi keberhasilan anggota keluarga, untuk mengimplementasikan hidup dan kehidupan. Di dalam keluarga anak kepada kedua orang tuanya, terutama ibunya. Sejak itulah proses pendidikan dimulai, dan dari situ pula pendidikan akan berakhir.

Tanggungjawab orang tua terhadap pendidikan anak adalah mutlak dalam keluarga sejak anak tersebut lahir hingga ia menemukan jati dirinya sendiri serta dapar bertanggungjawab terhadap tindakan yang di lakukannya sendiri. Peranan orang tua harus mampu milihat bakat yang muncul dari dari anaknya sendiri, dan dapat mengarahkan bakat anak tersebut untuk dilatih dan 
mencarikan guru yang baik sesuai kebutuhan bakat sang anak. Maka keluarga harus memberikan pendidikan yang baik dan meningkatkan motivasi kepada anaknya untuk terus belajar dan meberikan nasihat yang baik apabila anak tersebut berbuat kelalaian dalam berteman dengan anak yang kurang baik. Sebagaimana Sabda Nabi Muhammad SAW.

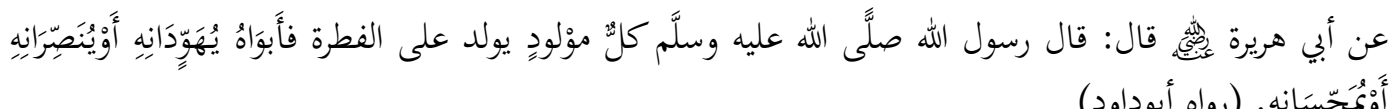

Artinya: "Dari Abu Hurairah, sesungguhnya dia berkata bahwa Rasulullah SAW telah bersabda: setiap kelahiran (anak yang lahir) berada dalam keadaan fitrah, maka kedua orangtuanya yang mempengaruhi anak itu menjadi Yahudi, Nasrani dan Majusi (HR. Abu Daud)."

Hadis diatas secara jelas menandakan bahwa peran orang tua sangat penting dalam membentuk pendidikan karakter, dan kepribadian terhadap anak agar lebih baik. Lingkungan merupakan alat pendidikan yang tanpa sadar mengitari anak. Meskipun kejadian atau peristiwa yang berada di sekeliling anak tidak dirancang namun keadaan tersebut memiliki pengaruh positif ataupun negatif terhadap pendidikan anak.

Orang tua dapat dikatakan berhasil memberikan pendidikan kepada anak sejak usia dini, apabila si anak mempunyai berprestasi dan kepribadian yang baik. Begitu juga sebaliknya, banyak anak memiliki karakter yang buruk akibat orang tuanya gagalnya dalam memberikan proses pendidikan dalam keluarga. (Arifin, 2018)

Pada perkembangan zaman saat ini, tanggungjawab orang tua menjadi sangat penting, mengingat banyaknya sendi kehidupan sosial yang menyimpang dari arah tujuan pendidikan, terkhusus kepada pendidikan keislaman, baik itu pengaruh dari media internet, media sosial, televisi atau tempat-tempat yang dilegalisasi untuk pelecehan seksual. Apabila orang tua tidak peran waspada dan siaga, berarti orang tua tersebut telah menyerahkan anak-anaknya pada genggaman setan dan pengikutnya. Berdasarkan permasalahan inilah penulis akan menguaraikan pola pendidikan dalam keluarga berdasarkan persfektif Hadist.

\section{METODE PEMBAHASAN}

Penulis akan menguraikan bagaimana hakikat dan pengertian pendidikan dalam keluarga; Apa saja hadits tentang pendidikan dalam 
120 | TAZKIR: Jurnal Penelitian Ilmu-ilmu Sosial dan Keislaman

Vol. 06 No. 1 Juni 2020

keluarga; Bagaimana metode pendidikan keluarga berdasarkan hadits; dan Apa saja aspek-aspek pendidikan keluarga berdasarkan hadist.

Penulis menggunakan metode kajian literatur (library research), dengan sumber data primer yaitu dari Hadits-hadits yang beriaktan dengan pendidikan anak dalam keluarga dan dari jurnal-jurnal terakreditasi yang membahas pola pendidikan keluarga berdasarkan persfektif hadis.

\section{HASIL DAN PEMBAHASAN}

\section{Hakikat Dan Pengertian Pendidikan Keluarga}

Keluarga ialah kelompok sosial kecil dalam lingkungan bermasyarakat,(Sutinah, 2019) dimana didalam keluarga tersebut dapat merasakan berbagai cinta dan kasih sayang antara suami atau istri dan anakanak, rasa cinta terhadap seluruh anggota keluarga lainnya.(Sutinah, 2015) Chaplin menyebutkan bahwa "keluarga adalah sekelompok orang yang dihubungkan oleh perkawinan atau darah yang secara khusus terdiri dari seorang ayah, ibu dan anak-anak".(Sutinah, 2015)

Keluarga merupakan suatu sistem dua arah antara orangtua dan anaknya yang diharapkan saling berhubungan. Adanya kerjasama dan timbal balik antara orangtua dan anak yang saling memperkuat jalinan keluarga serta keharmonisan dalam keluarga tersebut. (Wahy, 2012) Santrock menyebutkan bahwa "interaksi dua arah dalam sebuah keluarga disebut dengan Mutual Synchrony yang artinya perilaku setiap orang bergantung pada perilaku sebelumnya dari mitranya" (Santrock, 2002, p. 157), serta yang di maksud dengan mitra tersebut adalah orang tua, yaitu pihak kedua yang selalu berada didekat anak dan menjadi berbicara, relasi serta sosial anak.

Orang tua wajib untuk memberikan pendidikan yang terarah sesuai yang di ajarkan oleh Al-Qur'an dan hadist sehingga terbentuk anak yang shaleh dan berguna bagi masyarakat umum. Pendidikan ketauhidan, budi pekerti, dan moral perlu ditanamkan kepada anak sejak usia dini, sehingga terbentuk karakter yang jelas, dan berguna bagi bangsa serta agamanya.(Sukrillah, 2014) Dengan demikian, keluarga merupakan perkumpulan halal antara laki-laki dan perempuan yang terus menerus dimana satu sama lain merasa tentram dan nyaman sesuai dengan norma-norma agama dan sosial masyarakat. 


\section{Tujuan Pendidikan Keluarga}

Moh. Roqib menyebutkan orang tua adalah "manusia yang paling berjasa pada setiap anak. Semenjak awal kehadirannya di muka bumi, setiap anak melibatkan peran penting orang tuanya, seperti peran pendidikan".(Roqib, 2009, p. 39) Peran pendidikan seperti ini tidak hanya mejadi kewajiban bagi orang tua, tetapi juga menjadi kebutuhan orang tua untuk menemukan eksistensi dirinya sebagai makhluk yang sehat secara jasmani dan rohani di hadapan Allah dan juga di hadapan sesama makhluk, terutama umat manusia. (Murni, 2012)

Pendidikan dan akhlak merpakan Peran dan tanggung jawab orangtua untuk memberikan pendidikan kepada anak-anaknya. Para ahli bidang pendidikan telah menyebutkan bahwa keluarga mempunyai fungsi pendidikan yang paling utama bila dibandingkan dengan yang lainnya. (Suriadi et al., 2019) Mengenai fungsi pendidikan bagi keluarga, Allah SWT. Berfirman dalam AlQu'an sebagai berikut :

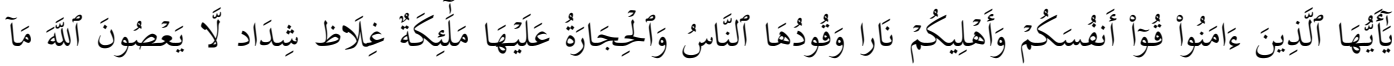

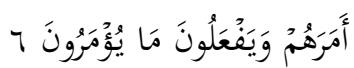

Artinya: "Hai orang-orang yang beriman, peliharalah dirimu dan keluargamu dari api neraka yang bahan bakarnya adalah manusia dan batu; penjaganya malaikatmalaikat yang kasar, keras, dan tidak mendurhakai Allah terhadap apa yang diperintahkan-Nya kepada mereka dan selalu mengerjakan apa yang diperintahkan". QS al-Taòrîm [66]: 6.

Dalam ayat di atas secara jelas Allah SWT mengajurkan kepada orang

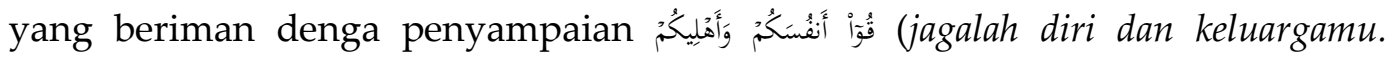
Kalimat tersebut mengandung kata fi'il Amr (kata perintah) untuk mendidik dan mengajarkan pendidikan keagamaan kepada anggota keluarga. Ayat ini mengutamakan pada pentingnya pendidikan nilai dan akhlak terhadap anggota keluarga. Al-Qusyairi mengatakan bahwa ketika turun ayat di atas, "Umar bertanya kepada Nabi SAW., "Ya Rasul Allah, kami dapat memelihara diri kami, akan tetapi bagaimana cara kami memelihara keluarga kami?" Rasul SAW. Menjawab, “Engkau larang mereka dari apa yang engkau dilarang Allah mengerjakannya, dan perintahkanlah mereka mengerjakan apa yang engkau diperintahkan Allah untuk mengerjakannya". (Suriadi et al., 2019); (Al-Qurtuby, 2002)

Dari penjelasan ayat tersebut sudah jelas bahwa demi kemaslahatan diri serta keluarga sudah menjadi kewajiban kepala keluarga untuk melindungi dan 
122 | TAZKIR: Jurnal Penelitian Ilmu-ilmu Sosial dan Keislaman

Vol. 06 No. 1 Juni 2020

mengarahkan anggota keluarganya ke arah yang benar sesuai ajaran yang diberikan oleh Allah dan Nabi-Nya. Pendidikan yang mengikuti syari'at Allah lah yang harus dijalankan oleh kepala keluarga untuk mewujudkan proses dan tujuan tersebut.

Dengan demikian, orangtua diwajibkan agar menjadi pendidik yang dapat meberikan pengetahuan, sikap dan keterampilan yang memadai, memimpin keluarga serta dapat memberikan contoh yang baik dan benar, dan bertanggung jawab dalam kehidupan berdasarkan anjuran yang difirmankan Allah SWT dan sunnah Rasul-Nya.

Chabib Thoha menyebutkan diantara tujuan pendidikan keluarga berupa: 1) Memberikan dasar pendidikan budi pekerti kepada anggota keluarga; 2) pendidikan sosial yang dapat melatih anak untuk bersosial yang baik kepada lingkungan sekitarnya; 3) pendidikan intelektual berupa kaidah pokok dalam berbicara, dan bertutur kata yang baik; 4) pembentukan kebiasaan yaitu, pembinaan kepribadian yang baik kepada anak untuk hidup teratur, disiplin, tertib, rajin, dan bersih; 5) pendidikan kewarganegaraan berupa, memberikan nilai-nilai nasionalisme dan patriotisme, cinta tanah air serta berprikemanusiaan yang tinggi. (Thoha, 1996, p. 112)

\section{Hadits Tentang Pendidikan Dalam Keluarga}

Pendidikan Islam ialah proses pembinaan individu yang di dasarkan dari pendidikan Islam untuk memperoleh derajat yang tinggi sehingga dapat menjalankan fungsi kekhalifahannya serta berhasil merealisasikan kebahagiaan dunia dan akhirat.(Nurhanifah, 2018) Pendidikan islam ini harus di mulai dari keluarga atau orang tua terhadap anggota keluarganya (anak-anaknya).

Anak merupakan generesi penerus yang akan memperoleh warisan terhadap nilai-nilai akidah keislaman serta budaya dari orang tuanya, serta mengembangkan dan menyebarluaskan nilai-nilai warisan tersebut hingga memiliki guna dan bermanfaat secara umum, bagi lingkungan sekitarnya. Sesuai halnya dalam pendidikan Islam, anak merupakan keturunan sebagai pewaris ajaran pendidikan Islam yang di kembangkan oleh Nabi Muhammad SAW dan generasi muslimlah yang akan meneruskan misi dakwah Islam ke-seluruh umat.

Dalam Islam, insan yang paling bertanggungjawab terhadap perkembangan anak didik adalah ayah dan ibunya. Tanggungjawab tersebut setidaknya memiliki faktor dua hal yaitu: pertama, disebabkan orangtua sebagai 
kondrat yang di takdirkan sebagai orang tua dari anaknya. Kedua, disebabkan kepentingan orang tua yang berkepentingan terhadap kemajuan apektif dan psikomotorik anaknya, kesuksesan anaknya menandakan kesusesan orang tuanya. (Rosyadi, 2004, p. 172)

Dalam ayat Al-qur'an dan hadist nabi Muhammad SAW banyak di temukan tentang eratnya hubungan anak terhadap orang tua, hak dan kewajiban antara anak dan orang tua, serta peringatan-peringatan tarhadap perilaku antara orang tua dengan anaknya. Hal-hal tersebut menunjukkan betapa pentingnya pola pendidikan atau pengajaran terhadap anggota keluarga. Demikianlah merupakan amanah yang diberikan Allah kepada umatnya, dan akan di mintakan pertanggungjawabannya di hari kemudian. Sesuai dengan firman Allah SWT Q.S. Tt-Tahrim ayat 6 dan sabda nabi Muhammad SAW.

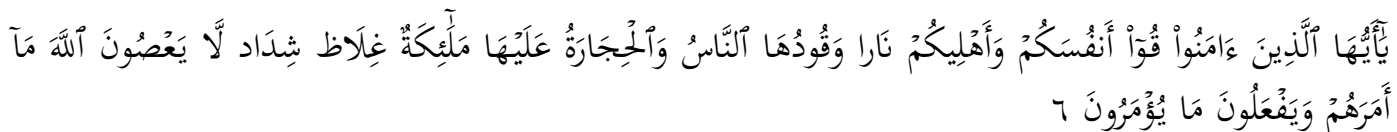
Artinya: "Hai orang-orang yang beriman, peliharalah dirimu dan keluargamu dari api neraka yang bahan bakarnya adalah manusia dan batu; penjaganya malaikatmalaikat yang kasar, keras, dan tidak mendurhakai Allah terhadap apa yang diperintahkan-Nya kepada mereka dan selalu mengerjakan apa yang diperintahkan". (Q.S. Tt-Tahrim:6)

Potongan ayat di atas terdapat kata فُ فُ Potongan ayat fi'il amr yaitu kata perintah untuk memelihara atau menjaga diri dan keluarga وَأَفْلِيكُم dari api neraka dengan cara menjauhkan perilaku tercela dan maksiat. Menjaga diri agar tidak mengikuti hawa nafsu, serta selalu taat melaksanakan ajaran dan perintah yang di berikan Allah.

Kemudia potongan ayat aَوَُو artinya "bahan bakar" yang dapat

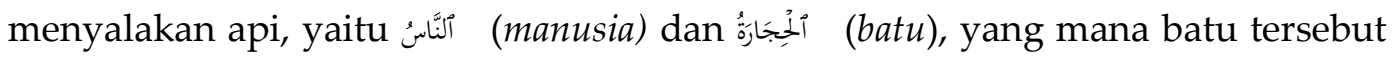

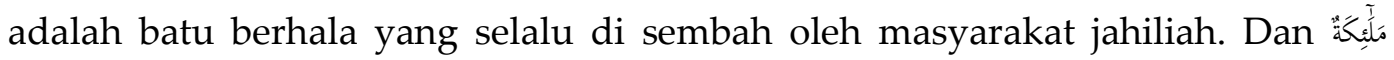

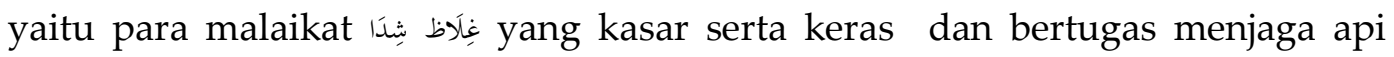
neraka, yang mana Allah telah mencabut dari hati para malaikat tersebut rasa kasih sayang terhadap orang-orang yang menduskan Allah yaitu orang kafir. Para Malaikat tersebut tidak akan mendurhakai Allah terhadap apa yang di perintahkan-Nya. (Ar-Rifa'I, 2000, p. 752)

Demikianlah perintah dan tanggung jawab yang diberikan Allah kepada orang tua untuk menjaga dan mendidik dirinya dan anggota keluarganya, 
124 | TAZKIR: Jurnal Penelitian Ilmu-ilmu Sosial dan Keislaman

Vol. 06 No. 1 Juni 2020

karena hal-hal tersebut akan di mintakan oleh Allah pertanggungjawaban di hari kemudian, sesuai sabda nabi Muhammad SAW:

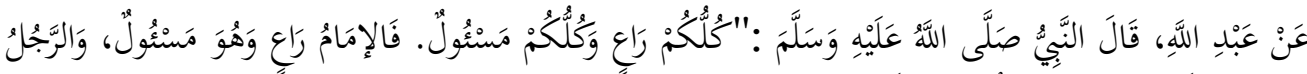

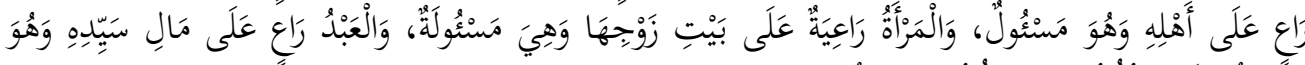

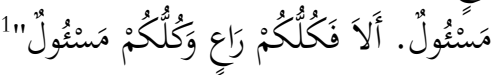

Artinya: "Setiap kalian adalah pemimpin, dan setiap kalian akan dimintai pertanggung jawabannya. Seorang imam adalah pemimpin dan akan dimintai pertanggungjawabannya. Seorang laki-laki adalah pemimpin atas keluarganya dan ia akan dimintai pertanggungjawabannya. Seorang wanita adalah pemimpin atas rumah suaminya, dan ia pun akan dimintai pertanggungjawabannya. Seorang budak juga pemimpin atas harta tuannya dan ia juga akan dimintai pertanggungjawabannya. Sungguh setiap kalian adalah pemimpin dan setiap kalian akan dimintai pertanggungjawabannya". (H.R. Bukhari Muslim: 4789)

Demikianlah kewajiban orang tua dalam memperhatikan pendidikan agama Islam terhadap anggota keluarganya (anak-anaknya) di dalam keluarga atau rumahnya. Abdurrahman An-nahlawi menjelaskan bahwa keluarga muslim ialah "keluarga yang mendasarkan aktivitasnya pada pembentukan keluarga yang sesuai dengan syariat Islam". (Risalah Muslim, n.d.)

Orang tua di berikan naluri untuk menyanyangi anak, naluri tersebut merupakan potensi yang di berikan Allah bersaman dengan penciptaan manusia dan binatang. Naluri tersebut di berikan Allah merupakan suatu landasan kehidupan alamiah mahluk hidup. Keluarga, utamanya orang tua bertanggungjawab untuk memberikan kasih sayang terhadap anggota keluarganya (anak-anaknya), karena kasih sayang merupakan faktor penting dalam perkembangan psikologis dan sosial anak.

\section{Metode Pendidikan Keluarga}

Bedasarkan Q.S. Tt-Tahrim ayat 6 dan hadits nabi Muhammad SAW yang di riwatkan H.R. Bukhari Muslim: 4789 diatas, maka kewajiban orang tua haruslah mendidik dan menjaga keluarganya berdasarkan pendidikan keislaman kepada anggota keluarganya, sesuai dengan hadits nabi Muahmmad SAW:

Artinya: "Anas berkata bahwa Rasulullah bersabda: Anak itu pada hari ketujuh dari kelahirannya disembelihkan akikahnya, serta diberi nama dan disingkirkan dari segala kotoran-kotoran. Jika ia telah berumur 6 tahun ia didik beradab susila, jika ia telah berumur 9 tahun dipisahkan tempat tidurnya dan jika telah

\footnotetext{
${ }^{1}$ (Risalah Muslim, n.d.)
} 
berumur 13 tahun dipukul agar mau shalat. Jika ia telah berumur 16 tahun boleh dikawinkan, setelah itu ayahnya berjabat tangan dengannya dan mengatakan, saya telah mendidik, mengajar, dan mengawinkan kamu, saya mohon perlindungan kepada Allah dari fitnah-fitnah di dunia dan siksaan di akhirat."(H.R. Ibnu Hibban).

Hadits tersebut menggambarkan tahapan tahapan pendidikan keislaman yang dpat di berikan kepada Anggota keluarga (anak). M. Furqon Hidayatullah menjelaskan tahapn tersebut adalah: (Hidayatullah, 2010)

a. Pendidikan tauhid.

Pada usia inilah anak awal di ajarkan kalimat tauhid. Pada saat anak baru lahir orag tua harus mengucapkan kalimat "La Illaha illallah". Sesuai dengan hadist Nabi "Jadikanlah kata-kata pertama yang diucapkan seorang anak kalimat La Illaha illallah. Dan bacakan kepadanya menjelang maut, kalimat La Illaha illallah". (H.R. Ibnu Abbas). Dari kalimat hadits tersebut Rasulullah telah jelas mengajarkan kepada para pengikutnya tentang penanaman tauhid kepada generasi penerusnya sejak dini. (Cahyono, 2017)

b. Pendidikan Budi Pekerti (Adab)

Pada usia anak sejak 4-6 tahun, orang tua harus mendidik anak untuk berbudi pekerti (adab) utamanya pada hal-hal sikap dan perilaku seperti jujur dan tidak bohong, memberikan pengenalak terhadap sikap dan perilaku yang benar dan tidak benar, dan memberikan pengenalan terhadap apasaja yang dapat diperintahkan dan yang tidak boleh dilaksanakan. Sebagaimana hadis Nabi menyebutkan:

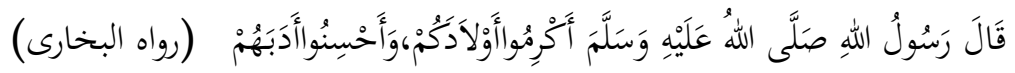

Artinya: "Muliakanlah anak-anakmu dan didiklah mereka dengan adab (budi pekerti) yang baik." (H.R. Bukhori)

Pendidikan kejujuran harus ditanamkan kepada anak sejak dini mungkin, serta diintegrasikan kedalam kehidupan berkeluarga, sekolah, masyarakat dan lingkungan sosial lainnya. Selain diajarkan terkait kejujuran, anak juga harus diajarkan terkait sikap dan perilaku, dan hal-hal yang baik dan tidak baik, sehingga anak mampu mebedakan mana yang hak dan mana yang bathil.

c. Penanaman Tanggung Jawab

Pada usia anak sejak (7-8 tahun), orang tua harus memerintahkan kepada anak untuk melaksanakan Shalat serta menunjukkan bahwa anak di 
126 | TAZKIR: Jurnal Penelitian Ilmu-ilmu Sosial dan Keislaman

Vol. 06 No. 1 Juni 2020

didik untuk bertanggungjawab, terutama pada dirinya sendiri. Sebagaimana hadis Nabi menyebutkan:

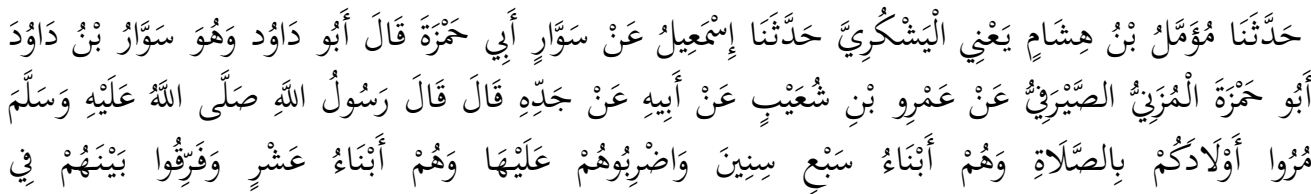
الْمَضَاجِعِ

Artinya: "Telah menceritakan kepada kami [Mu'ammal bin Hisyam Al-Yasykuri] telah menceritakan kepada kami [Isma'il] dari [Sawwar Abu Hamzah] berkata Abu Dawud; Dia adalah Sawwar bin Dawud Abu Hamzah AlMuzani Ash-Shairafi dari [Amru bin Syu'aib] dari [Ayahnya] dari [Kakeknya] dia berkata; Rasulullah shallallahu 'alaihi wasallam bersabda: Perintahkanlah anak-anak kalian untuk melaksanakan shalat apabila sudah mencapai umur tujuh tahun, dan apabila sudah mencapai umur sepuluh tahun maka pukullah dia apabila tidak melaksanakannya, dan pisahkanlah mereka dalam tempat tidurnya". (H.R. Abu Dawud:418)

Hadits diatas menjelaskan tentang pentingnya orang tua untuk mengajarkan kepada anak untuk melaksanakan ibadah shalat sejak usia 7 tahun, dan pada hingga usia 10 tahun apabila anak tersebut tidak mengerjakannya maka berikanlah pukulan (peringatan). Hal ini menunjukkan pentingnya rasa tanggungjawab terhadap diri seorang anak agar tidak meninggalkan shalat. Selain itu pada usia ini juga anak diajarkan untuk tertin dan disiplin, karena dalam pelaksanaan shalat anak juga dituntut untuk tertib, taat, serta disiplin.

d. Pendidikan Kepedulian (kasih sayang)

Kepedulian merupakan rasa empati kepada orang lain. Hal inilah orang tua harus menanamkannya kepada anak dan keluarganya. Sejak anak usia 9-10 tahun, anak talah terbiasa untuk bergaul dan berteman dengan sebayanya, pada masa inilah orang tua menanamkan rasa empati, dan saling menghormati kepada orang lain dan orang yang lebih tua, serta saling menyayang kepada orang yang lebih muda dari anak tersebut. Sebagaimana hadis Nabi menyebutkan:

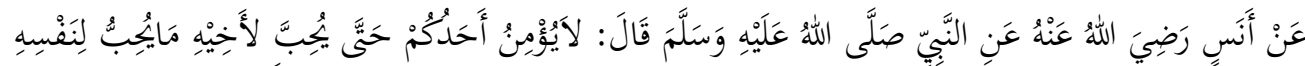

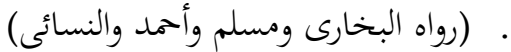

Artinya: "Anas ra. berkata, bahwa Nabi saw. bersabda, "Tidaklah termasuk beriman seseorang di antara kami sehingga mencintai saudaranya sebagaimana ia mencintai dirinya sendiri". (H.R. Bukhari, Muslim, Ahmad, dan Nasa'i) 
Berdasarkan hadits diatas, telah jelas rasulullah mengisyaraktkan kepada setiap individu agar saling mencintai dan menghormati satu sama lainnya. Dengan demikian pada usia inilah tepatnya anak diajarkan dan dilibatkan dengan nilai-nilai kepedulian dan kasih sayang kepada orang lain.

e. Pendidikan kemandirian

Pada usia 10 - 12 tahun, anak telah melalui berbagai pengalaman dari usia-usia sebelumnya. Anak semakin mematangkan karakter dirinya sendiri sehingga membawa dirinya kepada kemandirian. Pada fase kemandirian ini anak telah mampu mengenal, dan menerapkan apa-apa saja yang yang di perintahkan atau yang menjadi perintah, dan apa-apa saja yang dilarang dan menjadi larangan, serta telah memahami resiko atau konsekuensi jika melanggar aturan. (Kuswanto, 2016) Sesuai dengan firman Allah Q.S. (74) AlMuddaththir :38

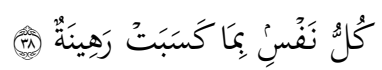

Artinya: "Tiap-tiap diri bertanggung jawab atas apa yang telah diperbuatnya" (AlMuddaththir :38)

\section{f. Pendidikan Bermasyarakat}

Pada usia diatas 13 tahun, anak dipandang telah memiliki kepribadian yang siap untuk bergaul dengan masyarakat dengan berbekal dari pengalaman-pengalaman yang telah dilalui sang anak dari tahun-tahun sebelumnya. Setidak-tidaknya orang tua hanya menanamkan nilai-nilai integritas dan kemampuan beradaptasi dengan lingkungan masyarakat. Jika tahap-tahap pendidikan yang di lalui anak sejak usia dini di lalui dengan baik, maka anak hanya tinggal menyempurnakan dan mengembangan kemampuan yang ia miliki untuk di implementasikan secara khusus pada dirinya, serta kepada masyarakat secara umum.

\section{DISKUSI}

Bedasarkan pembahasan di atas terkait pendidikan dalam keluarga, dapat di temukan pola-pola yang harus di implementasikan dalam lingkungan keluarga, untuk terbinanya keluarga bahagia sesuai yang di ajarkan oleh nabi muhammad SAW. Pendidikan dalam keluarga ini sejalan dengan firman Alah SWT pada QS. Lukman: 13-19 tentang pendidikan dalam keluarga.

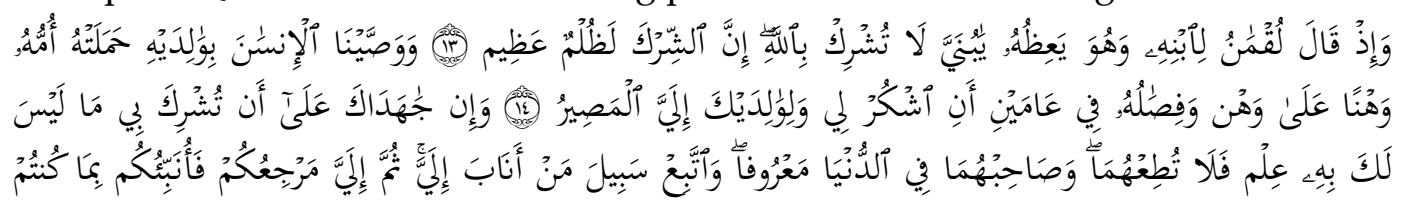


128 | TAZKIR: Jurnal Penelitian Ilmu-ilmu Sosial dan Keislaman

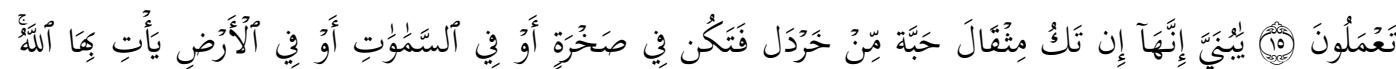

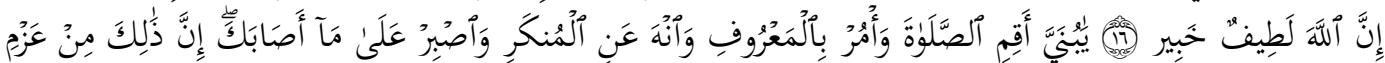

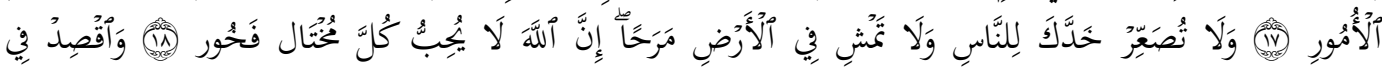

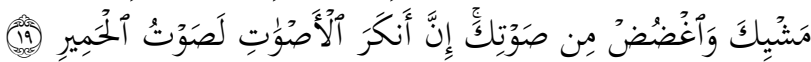

Artinya :13. "Dan (ingatlah) ketika Luqman berkata kepada anaknya, di waktu ia memberi pelajaran kepadanya": "Hai anakku, janganlah kamu mempersekutukan Allah, sesungguhnya mempersekutukan (Allah) adalah benar-benar kezaliman yang besar" 14. "Dan Kami perintahkan kepada manusia (berbuat baik) kepada dua orang ibu-bapaknya; ibunya telah mengandungnya dalam keadaan lemah yang bertambah-tambah, dan menyapihnya dalam dua tahun. Bersyukurlah kepada-Ku dan kepada dua orang ibu bapakmu, hanya kepada-Kulah kembalimu" 15. "Dan jika keduanya memaksamu untuk mempersekutukan dengan Aku sesuatu yang tidak ada pengetahuanmu tentang itu, maka janganlah kamu mengikuti keduanya, dan pergaulilah keduanya di dunia dengan baik, dan ikutilah jalan orang yang kembali kepada-Ku, kemudian hanya kepada-Kulah kembalimu, maka Kuberitakan kepadamu apa yang telah kamu kerjakan" 16. (Luqman berkata): "Hai anakku, sesungguhnya jika ada (sesuatu perbuatan) seberat biji sawi, dan berada dalam batu atau di langit atau di dalam bumi, niscaya Allah akan mendatangkannya (membalasinya). Sesungguhnya Allah Maha Halus lagi Maha Mengetahui" 17. "Hai anakku, dirikanlah shalat dan suruhlah (manusia) mengerjakan yang baik dan cegahlah (mereka) dari perbuatan yang mungkar dan bersabarlah terhadap apa yang menimpa kamu. Sesungguhnya yang demikian itu termasuk hal-hal yang diwajibkan (oleh Allah)" 18. "Dan janganlah kamu memalingkan mukamu dari manusia (karena sombong) dan janganlah kamu berjalan di muka bumi dengan angkuh. Sesungguhnya Allah tidak menyukai orang-orang yang sombong lagi membanggakan diri" 19. "Dan sederhanalah kamu dalam berjalan dan lunakkanlah suaramu. Sesungguhnya seburuk-buruk suara ialah suara keledai"

Berdasarkan ayat diatas dapat di uraikan bahwa Lukman memulai nasihatnya dengan menekankan pendidikan ketauhidan dan menghindari syirik/menyekutukan Allah. Pesan yang diberikan tersebut berbentuk larangan agar tidak mempersekutukan Allah serta meninggalkan segala perbuatan yang buruk. (Shihab, 2002, p. 127)

Pada ayat 14 menjelaskan tentang penekanan terhadap jasa-jasa Ibu. Hal ini disebabkan karena seorang Ibu memiliki potensi yang tidak di hiraukan akan kelemah lembutannya di banding dengan ayah. Walaupun perang seorang ibu tidak sebesar perang sorang ayah, akan tetapi jasa seoarang ibu tidak bisa diabaikan,oleh karena itu seorang anak haruslah berdo'a untuk ayah 
sebagaimana ia berdo'a untuk ibunya. Seperti do'a yang di contohkan dalam AlQuran (Qs. Al Israa' [17]:23):

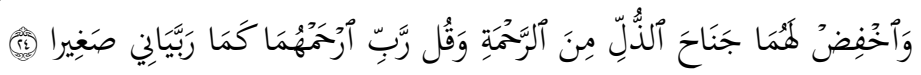

Artinya: "Dan rendahkanlah dirimu terhadap mereka berdua dengan penuh kesayangan dan ucapkanlah: "Wahai Tuhanku, kasihilah mereka keduanya, sebagaimana mereka berdua telah mendidik aku waktu kecil". (Qs. Al Israa' [17]:23)

Pada ayat ke 17 Lukman selanjutnya memberi nasihat terhadap hal-hal yang menyangkut dengan amal-amal shaleh, utamanya Shalat, serta amal-amal yang tercermin dalam amar ma'ruf nahi munkar, serta pesan terkait perisai yang dapat membentengi seseorang dari kegagalan, yaitu sabar dan tabah. (Shihab, 2002, p. 137)

Pada ayat 18 dan 19, Lukman memberikan nasihat kepada anaknya terkait dengan akhlak dan sopan santun, serta berinteraksi dengan sesama manusia. Pendidikan akidah, beliau selingi dengan materi pelajaran akhlak, agar peserta didik tidak jenuh dengan satu materi, akan tetapi untuk mengisyaratkan bahwa pendidikan akidah dan akhlak merupakan satu kesatuan yang tidak dapat dipisahkan. (Shihab, 2002, p. 139)

Proses pendidikan yang di contohkan oleh Lukman dalam memberikan pengajaran kepada anaknya bermula dari penanaman pendidikan tauhid, agar anak mau berbuat akhlakul karimah, mengembangkan kepribadian baik, dan menyenangi perbuatan, serta mengimplementasikan perbuatan baik(aman shaleh).

Sebagaimana Islam mengajarkan ketauhidan dengan mengucapkan Kalimat Toiyyibah. Dengan demikian maka anak akan terbiasa mengucapkan apa yang ada dalam hati dan pikirannya, dan tidak bertentangan pendidikan Islam. Selanjutnya pembiasaan terhadap sesuatu yang dapat di lakukan dan mencintai seoarng anak. Anak yang melakukan sesuatu bukan karena keterpaksaan akan membuatnya percaya diri dan tahan banting, hingga pada akhirnya dia menjadi orang yang berkarakter kuat dan cerdas menghadapi tantangan hidupnya.

\section{KESIMPULAN}

Pendidikan merupakan bagian terpenting dalam membentuk kehidupan manuasia yang memiliki Akhlak karimah dan berkemajuan. Pendidikan keislaman merupakan usaha yang dirancang untuk implementasikan secara sistematis untuk melindungi anak didik dalam memahami nilai-nilai sikap dan kebiasaan manusia yang berhubungan dengan Allah, (individu) diri sendiri, 
130 | TAZKIR: Jurnal Penelitian Ilmu-ilmu Sosial dan Keislaman

Vol. 06 No. 1 Juni 2020

antar sesama manusia, lingkungan sosial serta rasa nasionalisme berdasarkan nilai-nilai keagamaan, hukum, budi pekerti, adat dan budaya.

Pendidikan keislaman membutuhkan proses yang simultan dan berkesinambungan yang melibatkan aspek-aspek pembelajaran kedisiplinan dan kepatuhan untuk mengimplementasikan pendidikan keislaman terhadap anak didik.

Sebagaimana yang telah di jelaskkan pada pembahasan sebelumnya, beberapa metode pendidikan Islam yang dapat diberikan kepada anggota keluarga sejak anak baru lahir hingga ia dewasa berupa: pertama, pendidikan tauhid. Kedua, pendidikan budi pekerti atau nilai-nilai kejujuran dalam diri. Ketiga, pendidikan tanggungjawab atau perwujutan niat dan tekat dalam mengimplementasikan sesuatu. Keempat, Pendidikan kepedulian atau rasa empati terhadap orang lain, saling menghormati kepada yang lebih tua, serta menyayangi yang lebih muda. Kelima, pendidikan kemandirian atau penanaman terhadap apa-apa saja yang yang di perintahkan atau yang menjadi perintah, dan apa-apa saja yang dilarang dan menjadi larangan, serta telah memahami resiko atau konsekuensi jika melanggar aturan. Keenam, pendidikan bersosial dan bermasyarakat.

Pendidikan dalam keluarga inilah yang perlu di tanamkan kepada anggota keluarga. Karena keluargalah lembaga pendidikan pertama dan yang paling berpengaruh untuk menumbuh kembangkan psikologis dan psikomotorik anak. Pendidikan nilai-nilai keislaman, dan nilai-nilai sosial, akan lebih mudah dipahami dalam sanubari seorang anak ketika masih berada dalam lingkungan keluarga, serta pendidikan keislaman lebih mudah untuk dibentuk pada saat usia anak masih muda, selain itu lingkungan sekolah dan sosial masyarakat akan mendidik, dan melatihnya.

Dalam mengimplementasikan pendidikan dalam keluarga, orang tua dan anggota keluarga hendaklah saling memahami dan mengerti terhadap hak dan kewajiban sesama dalam keluarga tersebut. Orang tua memahami kebutuhan yang di harapkan oleh anak sepanjang kebutuhan anak tersebut baik, begitu juga sebaliknya anak didik menghormati dan menjalankan apa saja yang di sampaikan orang tua sepanjang tidak bertentangan dengan pendidikan Islam. sebagaimana pesan yang disampaikan oleh Khalifah Ali bin Abi Thalib, "Janganlah engkau memaksakan anak-anakmu sesuai dengan pendidikanmu, karena sesungguhnya mereka diciptakan untuk zaman yang bukan zaman kalian. Cetaklah tanah selama ia masih basah dan tanamlah kayu selama ia masih lunak". 


\section{DAFTAR PUSTAKA}

Al-Qurtuby. (2002). Al-Jâmi" li al-Ahkâm al-Qur"ân. CD. Created by Natata softwere.

An Nahlawi, A. (1995). Pendidikan Islam di Rumah, Sekolah dan Masyarakat. Gema Insani.

Arifin, S. (2018). Eksistensi Orang Tua Sebagai Pendidik dalam Perspektif Hadits. Jurnal Kariman, 6(2), 251-266.

Ar-Rifa'I, M. N. (2000). Taisiru al-Aliyyul Qadir li Ikhtishari Tafsir Ibnu Katsir. Maktabah Ma'arif.

Asfiyah, W., \& Ilham, L. (2019). Urgensi Pendidikan Keluarga Dalam Perspektif Hadist Dan Psikologi Perkembangan. Hisbah: Jurnal Bimbingan Konseling Dan Dakwah Islam, 16(1), 1-20. https://doi.org/10.14421/hisbah.2019.161-01

Cahyono, G. (2017). Pendidikan Karakter Perspektif Al Qur'an Dan Hadits. $A L-$ ASTAR, Jurnal Ahwal al-Syahsiyah Dan Tarbiyah, 5(1). http://www.staimempawah.ac.id/jurnal/index.php/Ats/article/view/3

Daradjat, Z. (1995). Pendidikan Islam dalam Keluarga dan Sekolah (cet. II). CV. Ruhama.

Hidayatullah, M. F. (2010). Pendidikan Karakter Membangun Peradaban Bangsa. Yuma Pustaka.

JavanLabs. (n.d.). Hadits Abu Daud Nomor 418 [Web Blog]. Tafsir AlQuran Online. Retrieved 8 December 2019, from https://tafsirq.com/hadits/abu-daud/418

Kuswanto, C. W. (2016). Menumbuhkan Kemandirian Anak Usia Dini Melalui Bermain. Darul Ilmi : Jurnal Ilmiah Pendidikan Guru Raudhatul Athfal, 1(2), 20-34. http://ejournal.radenintan.ac.id/index.php/darul/article/view/1470

Murni, S. (2012). Hubungan pendidikan agama dalam keluarga dan kecerdasan emosi terhadap perkembangan jiwa beragama anak di Madrasah Ibtidaiyah Negeri Medan [Tesis, UIN Sumatera Utara]. http://repository.uinsu.ac.id/2928/

Nurhanifah. (2018). Urgensi Pendidikan Islam Dalam Keluarga. At-Tafkir, 11(1), 117-131. https://doi.org/10.32505/at.v11i1.531

Risalah Muslim. (n.d.). HR. Bukhari: 4789 - Tentang Setiap Kalian Adalah Pemimpin - RisalahMuslim [Web Blog]. RisalahMuslim. Retrieved 8 
132 | TAZKIR: Jurnal Penelitian Ilmu-ilmu Sosial dan Keislaman

Vol. 06 No. 1 Juni 2020

December 2019, from https://risalahmuslim.id/setiap-kalian-adalahpemimpin/

Roqib, Dr. Moh. (2009). Ilmu Pendidikan Islam: Pengembangan Pendidikan Integratif di Sekolah, Keluarga dan Masyarakat. Lkis Pelangi Aksara. https://books.google.co.id/books?id=h9BqDwAAQBAJ

Rosyadi, K. (2004). Pendidikan profetik. Pustaka Pelajar.

Santrock. (2002). Perkembangan Anak Jilid 1. PT Erlangga.

Shihab, M. Q. (2002). Tafsir Al-Misbah: Pesan, Kesan, dan Keserasian Al-Qur'an (Vol. 11). Lentera Hati.

Sukrillah, S. (2014). Tafsir Pendidikan Tauhid Keluarga dalam Qs. Al-Baqarah 132-133. MUDARRISA: Jurnal Kajian Pendidikan Islam, 6(2), 277-300. https://doi.org/10.18326/mdr.v6i2.277-300

Suriadi, S., Mursidin, M., Kamil, K., \& Adnan, A. (2019). Pendidikan Agama dalam Keluarga. Tarbawi: Jurnal Ilmu Pendidikan, 15(1), 89-105. https://doi.org/10.32939/tarbawi.v15i1.326

Sutinah, S. (2015). Konsep Pendidikan Keluarga Sakinah. Journal Al-Manar, 4(1). https://doi.org/10.36668/jal.v4i1.65

Sutinah, S. (2019). Metode Pendidikan Keluarga Dalam Perspektif Islam. Journal Al-Manar, 8(1), 161-224. https://doi.org/10.36668/jal.v8i1.103

Thoha, C. (1996). Kapita Selakta Pendidikan Islam. Pustaka Pelajar.

Wahy, H. (2012). Keluarga Sebagai Basis Pendidikan Pertama Dan Utama. JURNAL ILMIAH DIDAKTIKA: Media Ilmiah Pendidikan Dan Pengajaran, 12(2). https://doi.org/10.22373/jid.v12i2.451

Yasin, F. (2008). Dimensi-dimensi Pendidikan Islam. UIN Malang Press. 